\title{
The Influence of Work Life Balance on Employee Satisfaction at Grand Hyatt Jakarta Hotel (Case Study of Food and Beverage Service Department Employees)
}

\author{
Sherina Tanuputri ${ }^{1}$, Nurbaeti $^{2}$, Fetty Asmaniati ${ }^{3}$ \\ 1,2,3 Sekolah Tinggi Pariwisata Trisakti \\ 1tanuputrisherina@gmail.com
}

\begin{abstract}
Work life Balance is a factor that can affect Employees' Job Satisfaction This study aims to analyze the influence of Work Life Balance on Employee Job Satisfaction in Food and Beverage Service Department at Grand Hyatt Jakarta Hotel. In this study, information was collected from 68 respondents by using questionnaires. The data has been collected, then analyzed by using simple regression analysis with SPSS program. The results of this study indicate that Work life Balance has significant effect on Employee Satisfaction at Food and Beverage Service Department of Grand Hyatt Jakarta Hotel with 0.000 significance level smaller than $\alpha$ $(0,050)$. The effect of Work Life Balance on Employee Job Satisfaction is $22.7 \%$. The results of the highest respondents on the Work Life Balance (Balance of Work Life) is a Balance of Satisfaction of $79 \%$ and on Job Satisfaction is about the Appreciation of $82 \%$.
\end{abstract}

Keywords: Work life Balance, Employee Job Satisfaction 


\section{A. Introduction}

Currently, hotel business is expanding rapidly in various regions in Indonesia. The existence of the hotel can absorb a large number of workers in providing services to its guests. This research was conducted at the Grand Hyatt Hotel Jakarta as one of the tourism businesses in hospitality. This hotel is one of the major hospitality industries in DKI Jakarta with a total of 718 employees in 2017.

Employees have an important role in both providing the best service to customers, and they are also an important resource in achieving company goals. To achieve the goals, all factors that can lead to job satisfaction should be considered. Employee satisfaction will bring about some benefits. First, it makes the employees more motivated since the company understands what employees need. Secondly, it will add on the job loyalty. Every division in a company needs to encourage an employee job satisfaction to provide a sense of comfort. This also happens at the Grand Hyatt Jakarta Hotel.

Employee job satisfaction can be affected by work life balance. Work life balance is a balanced situation between work life and personal life (Lockwood, 2003). Where work life balance in the view of employees is the choice of managing work obligations and personal or family responsibilities. Whereas in the view of the company work life balance is the challenge to create a supportive culture in the company where employees can focus on their work.

The level of employee resignation fluctuates every year due to various factors. Of the $9.74 \%$ voluntary resignations, the highest percentage was from the Food and Beverage Service department, which was 4.2\%. Work life balance might be one of the causes of the resignation. Grand Hyatt Jakarta Hotel must always maintain the satisfaction of its employees so that they can provide services according to the hotel's standard. Given the importance of employee satisfaction, it is necessary to know how much influence the Work Life Balance on Job Satisfaction. This issue is crucial so that the company is able to investigate the employee's need, and they will feel comfortable and able to improve their job performance at Grand Hyatt Jakarta Hotel.

\section{B. Literature Review}

Work life balance is defined as a situation when a person experiences balanced and satisfaction in his role as a worker and in the family (Greenhaus, Collins and Shaw 2003). Schermerhorn (2005) revealed that work life balance is a person's ability to balance work demands with personal and family needs. According to Delecta (2011) work life balance is defined as the ability of individuals to fulfill their work and family commitments, as well as other nonwork responsibilities.

Robbins and Coulter (2012) stated "Job satisfaction is an employee's general attitude toward his or her job". According to Handoko (2002) the definition or understanding of job satisfaction is a pleasant or unpleasant 
emotional state in which employees view their work. Decision of work reflects one's feelings about their work, employees see their work. Robbins and Judge (2013) state that job satisfaction is a positive feeling about one's job resulting from an evolution of its characteristics.

\section{Research Methodology}

This study was designed to observe and analyze the effect of work life balance on employee job satisfaction at the Grand Hyatt Jakarta Hotel. In this study there are two related variables, namely X (Work life Balance) and Y (Job Satisfaction).

This research employs a descriptive quantitative method to answer the problems of the circumstances. In addition, it studies phenomena as they are in the field or to know the contribution between variables in the phenomenon to be examined. In quantitative research the relationship between the researcher and the researched facts is assumed to be independent so that the researcher can objectively examine the reality of facts (Sukmana, Brahmantyo, \& Mumin, 2018).

\section{Participants / Subject / Population and Sample}

The population in this study were all employees at the Food and Beverage Service Department of the Grand Hyatt Jakarta Hotel, as many as 212 people. A probability sampling is used to get the sample as many as 68 respondents.

\section{Instruments}

In this study, primary data and secondary data were used as instruments to determine the results of the study. The data is from observation, interviews, questionnaires and supporting data such as company data and supporting theories.

\section{Data Analysis}

This study uses simple linear regression analysis by processing data using the statistical Package for Social Sciences (SPSS) version 20 for Windows. The stages of analysis are as follows: validity test, reliability test, average value (coefficient interval), simple linear regression.

\section{Result}

Based on the results of the study using a questionnaire distributed to 68 employees who were respondents in the Food and Beverage Service Department, the results were obtained and then processed and tabulated. Demographic characteristics of respondents include gender, age, status, education last and long work. 
The Influence of Work Life Balance on Employee Satisfaction at Grand Hyatt Jakarta Hotel (Case Study of Employees Food and Beverage Service Department)

Table 1. Responses of respondent on work life balance

\begin{tabular}{lcc}
\hline Statement & Average Score & Category \\
\hline $\begin{array}{l}\text { Working in accordance with the working } \\
\text { hours set by the company. (X1) }\end{array}$ & 3.93 & Agree \\
$\begin{array}{l}\text { The time given to the family outside of } \\
\text { work. (X2) }\end{array}$ & 3.47 & Agree \\
$\begin{array}{l}\text { The employee's responsibility to his or } \\
\text { her job. (X3) }\end{array}$ & 3.69 & Agree \\
$\begin{array}{l}\text { Sharing responsibility between work and } \\
\text { family (X4) }\end{array}$ & 3.09 & Agree \\
$\begin{array}{l}\text { Employee satisfaction with what has been } \\
\text { obtained from work. (X5) }\end{array}$ & 3.79 & Agree \\
Satisfied with the results of work. (X6) & 4.07 & Agree \\
\hline
\end{tabular}

Table 2. Responses of respondent on job satisfaction

\begin{tabular}{lcc}
\hline Statement & Average Score & Category \\
\hline Challenging job (Y7) & 4.1 & Agree \\
An interesting job. (Y8) & 4.06 & Agree \\
$\begin{array}{l}\text { The work is appreciated by the } \\
\text { company(Y9) }\end{array}$ & 4.01 & Agree \\
$\begin{array}{l}\text { Bosses like to thank the employees if it } \\
\text { can finish the job properly. (Y10) }\end{array}$ & 4.2 & Strongly \\
$\begin{array}{l}\text { A safe and comfortable employee work } \\
\text { environment. (Y11) }\end{array}$ & 3.93 & Agree \\
$\begin{array}{l}\text { The work atmosphere provides a high } \\
\text { motivation for employees. (Y12) }\end{array}$ & 3.94 & $\begin{array}{c}\text { Agree } \\
\text { Satisfied and pleased with the attitude of } \\
\text { colleagues. (Y13) }\end{array}$ \\
$\begin{array}{l}\text { Colleagues really help my work. (Y14) } \\
\text { Agree }\end{array}$ & 3.43 & Agree
\end{tabular}

Based on the analysis that has been done, the results of testing the validity of the two variables, namely Work life Balance and Employee Job Satisfaction can be shown from the following table: 
The Influence of Work Life Balance on Employee Satisfaction at Grand Hyatt Jakarta Hotel (Case Study of Employees Food and Beverage Service Department)

Table 3. Variable X Validity Test Results (Work Life Balance)

\begin{tabular}{|c|c|c|c|c|}
\hline \multirow{2}{*}{ Variable } & \multirow{2}{*}{ Sub Variable } & $\mathrm{r}$ & $\mathrm{r}$ & \multirow{2}{*}{ Category } \\
\hline & & value & table & \\
\hline \multirow{6}{*}{$\begin{array}{l}\text { Work life } \\
\text { Balance }(\mathrm{X})\end{array}$} & \multirow{2}{*}{ Time (X1) } & .368 & .201 & Valid \\
\hline & & .313 & .201 & Valid \\
\hline & \multirow{2}{*}{ Involvement (X2) } & .295 & .201 & Valid \\
\hline & & .301 & .201 & Valid \\
\hline & \multirow{2}{*}{ Satisfaction (X3) } & .342 & .201 & Valid \\
\hline & & .489 & .201 & Valid \\
\hline
\end{tabular}

Table 4. Variable Y Validity Test Results (Job Satisfaction)

\begin{tabular}{|c|c|c|c|c|}
\hline \multirow{2}{*}{ Variable } & \multirow{2}{*}{ Sub Variable } & $\mathrm{r}$ & $\mathrm{r}$ & \multirow{2}{*}{ Category } \\
\hline & & value & table & \\
\hline \multirow{8}{*}{$\begin{array}{l}\text { Job } \\
\text { Satisfaction } \\
\text { (Y) }\end{array}$} & \multirow{2}{*}{$\begin{array}{c}\text { Mentality } \\
\text { Challenging (Y1) }\end{array}$} & .492 & .201 & Valid \\
\hline & & .368 & .201 & Valid \\
\hline & \multirow{2}{*}{$\begin{array}{l}\text { Equitable Rewards } \\
\text { (Y2) }\end{array}$} & .322 & .201 & Valid \\
\hline & & .399 & .201 & Valid \\
\hline & \multirow{2}{*}{$\begin{array}{l}\text { Supportive Working } \\
\text { (Y3) }\end{array}$} & .373 & .201 & Valid \\
\hline & & .422 & .201 & Valid \\
\hline & \multirow{2}{*}{$\begin{array}{c}\text { Supportive } \\
\text { Colleageus (Y4) }\end{array}$} & .388 & .201 & Valid \\
\hline & & .382 & .201 & Valid \\
\hline
\end{tabular}

Table 5. Realibility Test Result

\begin{tabular}{lcc}
\hline Statement & $\begin{array}{c}\text { Average } \\
\text { Score }\end{array}$ & Category \\
\hline 0.756 & 0.7 & Reliable \\
\hline
\end{tabular}

This result is a simple regression test on research regarding work life balance on employee job satisfaction at the Grand Hyatt Jakarta Hotel.

Table 6. Simple Linear Regression Analysis Results

\begin{tabular}{|c|c|c|c|c|c|}
\hline Model & Unstandardized & Coefficients & Standardized & $\mathrm{t}$ & Sig \\
\hline (Constant) & $\mathrm{B}$ & Std. Error & Coefficients & & \\
\hline Work Life & 2.293 & .385 & Valid & 5.96 & .000 \\
\hline Balance & .449. & .102 & Valid & 4.40 & .000. \\
\hline
\end{tabular}


Based on the results in Table 6 , it shows that the constant value (a value) obtained is equal to 2.293 and the coefficient value (value of b) is equal to 0.449 so that the linear regression equation is:

$$
\mathrm{Y}=2.293+0.449 \mathrm{X}
$$

From the regression equation above, it can be interpreted as follows: 1. The value of the equation constant above states that if there is no Work Life Balance value (variable $\mathrm{X}$ ) then the value of Employee Job Satisfaction (variable $\mathrm{Y}$ ) is only 2.293. A positive constant value indicates a positive influence of the independent variable on the dependent variable.

2. The regression coefficient of 0.449 states that each addition of 1 Work Life Balance value (variable $\mathrm{X}$ ) will increase the value of Employee Job Satisfaction (variable Y) of 0.449 .

Table 7. Determination Coefficient

\begin{tabular}{ll}
\hline $\mathrm{R}$ & $\mathrm{R}$ \\
& Square \\
\hline $.476^{\mathrm{a}}$ & .227
\end{tabular}

The data in the table above, the $\mathrm{R}$ square value of 0.227 shows that the variation of the variable employee job satisfaction (variable $\mathrm{Y}$ ) can be explained by the variable work life balance (variable $\mathrm{X}$ ) of $22.7 \%$, while the rest is influenced by other factors outside of this study.

\section{E. Conclusion}

Based on the results of the above research, it can be seen from the responses of respondents who agreed on the Satisfaction Balance of $79 \%$. Then the respondent's response to Time Balance was $74 \%$ and the Engagement Balance was only $68 \%$. It is meant that the company should improve the work life balance of employees until employees achieve job satisfaction. If the work given by the employee can be appreciated by the employer or company properly, it can lead to satisfaction with the employee, so that employees will tend to be satisfied with the results of their work and provide maximum performance. The conclusion is that employees must be smart to choose or share their responsibilities and priorities. So if the company wants to improve job satisfaction through Work life Balance, the company must focus on improving the balance of engagement (X2) first without forgetting the increase in time balance (X1) and satisfaction balance (X3).

The results of the responses given by respondents regarding Job Satisfaction in the Food and Beverage Service Department can be seen with the highest results of $82 \%$ in respect of equal rewards, followed by mentally challenging work with the same percentage. Then responses regarding the 
The Influence of Work Life Balance on Employee Satisfaction at Grand Hyatt Jakarta Hotel (Case Study of Employees Food and Beverage Service Department)

supportive work environment were $79 \%$ and responses of $72 \%$ regarding supportive colleagues. The results above can be concluded that awards from superiors and companies are very influential to improve employee job satisfaction. The company should maintain all forms of appreciation or appreciation such as verbal praise or verbal and material such as giving bonuses or proposing promotions that will greatly affect the increase of satisfaction that will have an impact on employee work productivity.

Work life Balance has a significant effect on Employee Job Satisfaction. This can be seen from the results of $t$ count with the Work life Balance variable of 4.402. Work life balance or Work life Balance simultaneously affects employee job satisfaction. This can be proven from the results of the $r$ square value of 0.227 which has the understanding that Employee Job Satisfaction is influenced by Work life Balance which is $22.7 \%$. The results of the F test (ANOVA) is the calculated $\mathrm{F}$ value of 19.3777 which is greater than the $\mathrm{F}$ table with a significance value <probability $(0.000<0.05)$. Coefficient value from Work life Balance that is equal to 0.449 which shows a positive relationship to Employee Job Satisfaction. It can be concluded that if there is an increase in Work life Balance, then Employee Job Satisfaction will also increase.

\section{REFERENCES}

Delecta, P., (2011). Work life Balance. International Journal of Current Research $3 \mathrm{Vol}$ 4, hlm 186-189.

Greenhaus, J. H., Collins, K. M., dan Shaw, J. D., (2003). The Relationship between work-family balance and quality of life. Journal of Vacational Behaviour Vol 63.

Handoko, T. Hani., (2002). Manajemen Personalia dan Sumber Daya Manusia. Edisi II. BPFE. Yogyakarta.

Lockwood, Nancy R., (2003). Work life Balance: Challenges and Solutions. SHRM Research Department.

Robbins, Stephen P., dan Coulter, Mary., (2012). Management. New Jersey: Pearson Education, Inc.

Robbins, Stephen P., dan Judge, Timothy A., (2013). Organizational Behavior. Fifteen Edition: Pearson. England.

Schermerhorn., (2005). Management $8^{\text {th }}$ ed, John Wiley \& Sons, Inc. USA

Sukmana, Eman., Himawan Brahmantyo, and Adhi Trirachmadi Mumin. 2018. The Influence of Community Participation, The Role of Village Government, Number of Tourist Visits, and Village Income on Community Welfare in Cibuntu and Citundun Tourism Villages. Tourism Research Journal. Vol. 2, No. 2: 61 - 77. 